\title{
Perspectives on church and mission: The missional church and metaphors for the church
}

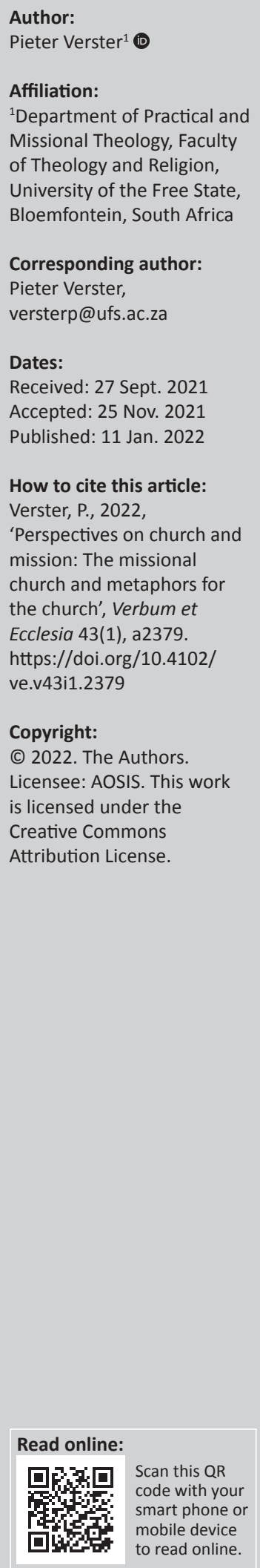

The most important issues for the missional church should be to establish the relation between mission and the church. The methodology used is to listen to voices concerning relevant issues in the missional church. Many important aspects of the missional church are discussed to give an overview of contemporary challenges. Metaphors for the church, such as people of God, body of Christ, temple of God, bride of Christ and witness of God give many essential guidelines for how the church should engage the world. By evaluating these metaphors, new suggestions can be made. It is concluded that the church should always be the church of the living Christ, living new lives in this world with the eye on the world to come.

Intradisciplinary and/or interdisciplinary implications: The relation of the Church and mission is of great importance. In the discipline of Missiology current ideas about the missional church call for new interpretations. Only by thoroughly interacting with the metaphors of the church can the missional church be understood in a new way.

Keywords: church; mission; metaphors; missional; relation to Christ.

\section{Introduction}

It is crucial to discuss the relation between mission and church. The church is God's church, and mission should always be in relation to the living Triune God. God calls upon the church to follow him in proclaiming and living the gospel. Missio Dei, missio ecclesiae and the missio humanitatis form the basis of the relation between the church and mission. The influence of the church relates to every inch of the mission endeavour. The current enormous challenges for mission include poverty, wars and violence, cultural differences, post- and new-colonialism, and the COVID-19 pandemic. Mission is understood as the glorious proclamation in word and deed over many borders such as faith and non-faith and church and non-church to lead the people out of darkness to God's wonderful light in all aspects of their lives for this life and the eternal life with God (see Van Engen 1996). The present views of the church regarding mission are, therefore, very important. Newbigin's (1989) interpretation of the church to be the church in this world living for God is relevant. The church should be the realisation of the gospel in the world. The Gospel must be visible in the church.

\section{Nikolajsen (2013a) writes in this regard:}

Thus, Lesslie Newbigin and the GOCN passed on the church-centred interpretation of missio Dei-as well as a tradition of theological integration of church and mission - which we find in the ecumenical movement in the mid-20th century. With this in mind, mission is regarded as the essential nature and calling of the church. In this way, missional ecclesiology guards itself against, on the one hand, a dissociation of mission from the church (the modern mission movement) and, on the other hand, a dissociation of the church from mission (the world-centred interpretation of missio Dei). (p. 261)

It is important to explain the concepts of missio Dei, missio ecclesiae and missio humanitatis as they form the foundation of relating mission and the church. The essence of the missio Dei is that God is the sending God in sending His Son to the world. The Son sends the Church into the world to present the living God. The human person is then empowered in the world by the living God by his Son and through the Holy Spirit. Bosch (1991:390) explains the very important understanding of the missio Dei as an 'attribute' of God. God is known as the sending God. This is exactly the way in which God presents Himself. Mission is then God coming to the world in His Son Jesus Christ. The revelation of God as the sending God makes mission possible. Participation in mission is also part of the knowledge of God. Mission is therefore non-negotiable for those who know God. Bosch's influence on the theology of mission cannot be underestimated. His understanding of the ecumenical paradigm for mission leads to a new view of the missional church as the comprehensive ecumenical people of God. This has implications for the role the church plays in society. Extremely 
important is that Bosch regards the church from the perspective of the missio Dei. God sends the church in the world, because it is God's church. He, as the sending God, determines the church.

The concepts of the missional church were developed from these ideas. The missional church is the church that lives in this world according to the gospel to present Christ to all. Guder's (1998:25) introductory book explains that mission has to be understood from the missio Dei, that is, from the hearth of God and not something added to the church mission, which many other voices have followed, and even Bell's (2011) emerging church movement is sometimes regarded as missional church movement. Goheen (2014:482-483) refers to the implications of the church as the new alternative community of God living in the world and not only the community of Western Christendom. Van Engen's (1991:41ff.) book God's Missionary People: Rethinking the Purpose of the Local Church, which conveyed the essential message that the church must become what she is, remains an important work regarding the missional church.

Hughson (2011) explains that there are still many different opinions, regarding the way in which the missional church should be seen as influencing the public society:

Whether or not and how worship, prayer, contemplation, selfoffering, and ministry of Word and Sacrament have, can have, or should have an impact in a pluralist public square remains open for discussion. (p. 194)

One should, however, understand that the missional church must be regarded as a totally comprehensive church, influencing all aspects of society.

\section{The missional church}

Many of the exponents of the missional church explained that the church is God's missionary people who have to bring about change in the community by allegiance to Jesus Christ, the glorious Christ. But he is also the Jesus of relations. Jesus and his Father and the Holy Spirit live in relation to one another and this relation must also be present in the relations of the church in the world.

Maclvaine III (2010:91) explains: 'A missional church is a unified body of believers, intent on being God's missionary presence to the indigenous community that surrounds them, recognizing that God is already at work'.

\section{Van Gelder (2004) adds:}

In the biblical framework outlined here, the missional church is identified as living between the times. It lives between the now and the not yet. The redemptive reign of God in Christ is already present, meaning that the power of God is fully manifest in the world through the Gospel under the leading of the Spirit. (p. 445)

The uniqueness of the missional church is clear. Van Rheenen (2006:30) regards the missional church as a different form of the church growth movement in the sense that the missional movement emphasises 'theological reflection and historical perspective' and 'the church growth movement [emphasises] cultural analysis and strategy formation'.

Many aspects of these relations must thus be emphasised. Firstly, the relation to the Triune God, from which religion is understood as a new way of living. This means that one experiences the gospel in new relations. Glorious is then the relation with the living God and true religion should also be understood in this regard. Jesus as Person in the Trinity helps one to understand the different relations in which one finds oneself. The missio Dei has the implication that the missional church must always be understood from the perspective of the Trinity, namely that the sending God is in deep relation with the sending Son who sends the church through the Holy Spirit.

Secondly, the church should be the radical church for change in the community. The church should bring about change in many instances. Prebble (2014:225) opines that the church should move from the emphasis on institution to that on a community of people. This should always be regarded in light of the missio Dei. God's mission determines the people. In this regard, Christology is of paramount importance. Christ should always be the essence of the missional church.

The church brings about a new understanding of the believers and their neighbours. The change that the church brings about in the community should be radical in the sense that people are now viewing the world in a new way. The church should be a community that is present and living in this world. The fact that the church should relate to people in this world is radically important. Congregations should emphasise not only going to heaven and avoiding hell but also new relations.

Baron and Maponya (2020) explain that the prophetic aspect of being a church should be emphasised. The missio Dei also determines the people of God and how they should live prophetically in this world. It is important that, in all aspects of life, the connection with the living God must be proclaimed in word and deed. In this regard, it is clear that the Spirit is the vehicle of the glory of God.

Van Gelder (2004) refers to the same matter:

The kingdom of God, the redemptive reign of God in Christ, gives birth to the missional church through the work of the Spirit. Its nature, ministry, and organization are formed by the reality, power, and intent of the kingdom of God. Understanding the redemptive purposes of God that are embedded within the kingdom of God provides an understanding of the church being missionary by nature. The church participates in God's mission in the world because it can do no other. It was created for this purpose. (p. 445)

Thirdly, the emphasis should be on helping people in need. Poverty-stricken people should be helped to understand how they can relate to the different aspects of their lives. The church should, therefore, not only be a church of the soul but 
also a church of the body. The relations of people towards one another in poverty should be regarded as very important. The missio Dei always regards the mission humanitatis as the purpose of the mission of the church.

Fourthly, the church should seek justice. Baron (2019) explains that the notion of corruptio totalis is important in order to understand that even the church is not free of $\sin$ in the sense of corruption:

Is it therefore not important that the church not only perceives its role in terms of opposing corruption, but also acknowledges and confesses its own contribution in the evolvement of corruption in society? It should be, alongside the media, vocal of the universal and radical nature of sin in the world - which all boils down to corruptio totalis. (p. 7)

In order to emphasise the glory of God, justice is sought for the community and for all people. The church should, therefore, be the church of justice, seeking justice; glorifying God by doing justice. The question remains: What is justice? Because this is such a difficult concept in the world, it is important to see different aspects of this in relation to one another. All these different aspects have implications for how we understand the church. Peterson (2015:164) refers to this aspect: 'The theology of the cross calls for a new vision of the church, one shaped by the cross'.

\section{Niemandt (2012) refers to an important issue:}

There is a rediscovery of missional ethics, especially as a matter of counter cultural witness. The understanding of mission is certainly no longer limited to evangelism, or social action, but is understood as an outflow of these theological convictions of a living God who has acted in redeeming the whole creation to him. 'Missional ethics' speaks of the missionary dimensions of the life of the people of God and the ethical features of mission. This connection between mission and ethics is fundamental for how life in the Spirit is perceived. (s.p.)

Niemandt (2012) lists the very important issues in missional theology:

The trends in missional ecclesiology were tracked by focusing on an incarnational approach to the church; relationality in the community of believers; the role of the kingdom of God; discernment as the first act in mission; imago Dei and creativity; the ecclesia and local community and finally mission and ethics. (s.p.)

Niemandt (2014:42) presents a comprehensive view on how the missional church should always be understood from the incarnation of Christ. In this sense, the marginalised should always be in the centre of the proclamation of the incarnation of Christ. He also refers to the concept of deep incarnation to emphasise that the incarnation of Christ has meaning for the whole of creation (Van Niekerk \& Niemandt 2019:8). The missional church, therefore, is a complete and comprehensive view of the church. He explained that the divinity and humanity of Christ should be confessed so that people in need receive the fullness of the incarnation. True life is experienced for all when the love of God is a realty in the church (Niemandt 2015b:339). A deep Christological emphasis on Christ as Saviour should be emphasised. In dialogue with Niemandt, this should receive a great deal of attention. A deep Christological approach is needed. All other aspects should be regarded in the light of Christology because Christ is the head of the church and the one who gave his life for the church.

What is important regarding the missional church? The church is God's missionary people (van Engen 1991:61-66). van Engen gives attention to the marks of the church as the understanding of the Word, as Word of God, the true presentation of the sacraments and the true application of church discipline. Link to the marks are the essential aspects of the church, namely One, Holy Apostolic church being 'adverbs' and not 'adjectives'. From this perspective, van Engen regards the church as totally unique in the world. The church is a new community, one in Christ, living as the community entrenched in the apostolic faith. The church belongs to the God in Jesus Christ through the Holy Spirit and is called upon to be the new people of God in society.

The church should renew all aspects of culture, society and environment. The church should, however, still be extremely important in leading people from darkness into the wonderful light in Jesus Christ. Whenever exponents of the missional church downplay this aspect, it must be rejected. This is clearly not the only aspect of the church's existence in the world but it must still be considered. All the people of God must proclaim and present the entire Gospel to the whole world. The missional church is vibrant and growing. The missional church and mission should also be regarded in light of the metaphors for the church.

\section{Metaphors for the church}

From these perspectives, one must now study the metaphors for the church, namely the church as people of God, body of Christ, bride of Christ, temple of God and witness of God. Migliore (2004:252-254) refers to the metaphors or images of the church as seen in the light of the coming reign of God, but that a warning must be issued that the church has not already realised the kingdom of God. Waiting for the fullness of the reign of God, the church looks up to God. There are many analogies, metaphors and images of the church. Migliore (2004:252-254) clusters them together in four images, namely people of God, servant people, body of Christ, and community of the Spirit. Relating to these images the following metaphors are emphasised, namely people of God, body of Christ, temple of God, bride of Christ and witnesses to the glory of God.

\section{The church as the people of God}

As the people of God, the church is the missional community that proclaims and emphasises that we have to belong to God. Bosch (1991:370-372) explains that a comprehensive view of the people of God and the implications for the whole 
of creation should be emphasised. God is the primary author of mission and not the church and therefore mission has to do with all God's creatures. Wright (2006:398-400) also refers to the fact that the people of God have implications for the whole of creation. The creation is the good creation of the good God and is intrinsically good. Therefore, God's people must also relate to the good creation and the people in the world. This does not mean that the people of God are the called out people of God, but that they live among others and in the world as God's messengers of renewal.

In this regard, the qahal Yahweh in the Old Testament was the assembly of God that was called out; they were the people belonging to God in a very special sense. God stretched out his hand to them, saying I am a Holy God, you are my people. I am God, you are my people. You should be Holy, but you are called out to be my people. These people have a very special meaning for the world (see Zachariah 8:23). In Joel 2:15-16, the prophet explains the implications of the assembly of God:

15 Blow the trumpet in Zion, declare a holy fast, call a sacred assembly.

16 Gather the people, consecrate the assembly; bring together the elders, gather the children, those nursing at the breast. Let the bridegroom leave his room and the bride her chamber.

\section{Joel 1:14:}

Declare a holy fast; call a sacred assembly. Summon the elders and all who live in the land to the house of the LORD your God and cry out to the LORD.

\section{Nehemiah 8:18:}

Day after day, from the first day to the last, Ezra read from the Book of the Law of God. They celebrated the festival for seven days, and on the eighth day, in accordance with the regulation, there was an assembly.

The people of God, the assembly of God, is the people of God who are called out, so that many people see in them the deliverance of God. It is very important to understand the Church in relation with Israel: the elect people of God in the Old Testament. Covenant and election are therefore extremely important aspects of the church as people of God (Migliore 2004:253).

Carpenter (1997:889) explains the implications of the qahal Yahweh well. It is clear that the assembly is called together in different ways. It is very important that it is the community gathered for worship, while being as holy as Moses. This is the special community of God. It, however, does not mean that the nations are rejected (Preuss 1996:285). The other is still important for the assembly of God. God has a way with all the nations of the world (Preuss 1996):

Even so, according to Amos 9:7, YHWH has set not only Israel but also other nations on a historical journey under divine guidance. Election faith and thought tend toward a certain universalism. (p. 285)
Preuss (1996:285) however, stated that the strong emphasis on monotheism must also be regarded. The relation to God of the community of God is paramount. Although community is very important in the covenant and in the assembly of God, it does not mean that the individual is unimportant. Eichrodt (1967) explains:

Incorporated into the cultic community of the amphictyony the Israelite experiences in the cultic action the real selfcommunication of his God through the priestly proclamation of his holy ordinances, and rejoices in the covenant favour and the covenant promises. (pp. 239-240)

This is extremely important in the New Testament. The people of God are called out by God; they are called to be the One, Holy Church of Christ. They live in this sense a new life, proclaiming the Word of God. In the world they also have the opportunity to relate to all people as created by God. Being people of God means that the church is also people of a different world; they are people of heaven. They are looking up to heaven (Col 3:1-5). This does not mean that they reject what they have to do on earth, and that there is not a good relation towards other people and doing what can be done on earth to emphasise the Kingdom of God. They also want to renew this world. Reference to the good creation of God is therefore also essential (Wright 2006:403-407). There is, however, another world, a new world. The people of God yearn for the future of God, and the coming of God in His total future. This means that the church will always be glorious in proclaiming the Word of God to all people. Billings (2008:58ff.) explains this well: 'It is impossible to belong to Jesus Christ without becoming members of his body. Salvation never happens between just an individual and Jesus'.

In the New Testament, some texts explain the special meaning of church.

Acts 20:28:

Keep watch over yourselves and all the flock of which the Holy Spirit has made you overseers. Be shepherds of the church of God, [a] which he bought with his own blood.

Ephesians 1:22-23:

And God placed all things under his feet and appointed him to be head over everything for the church, which is his body, the fullness of him who fills everything in every way.

Acts 12:1:

It was about this time that King Herod arrested some who belonged to the church, intending to persecute them.

In this regard, Pryfogle (2018:377) wrote: 'Ekklesia is an evocative metaphor, for it calls out the gifts needed for the common good, thereby catalyzing creation. Ekklesia moves witnesses toward generative possibilities'.

Revelations 21:3 clearly explains the way in which God dwells in the church as his people: 
And I heard a loud voice from the throne saying, 'Look! God's dwelling place is now among the people, and he will dwell with them. They will be his people, and God himself will be with them and be their God'.

1 Peter explains the implications of the church as the people of God very clearly.

Flemming (2014) refers to these aspects:

As we noted earlier, Peter's first concern in this passage is with what God's people are. But their identity as God's chosen, holy people also gives them a purpose in the world. This community of priests exists in order that (ó $\pi \omega \varsigma)$ it might proclaim the liberating and loving acts of God. Some interpreters argue that the term 'proclaim' in this verse is not missionary language. Rather, it is only about the kind of declaring that happens when God's people praise him in their public worship. Others, in contrast, think this verb specifically has to do with witnessing to unbelievers. In other words, Peter wants his readers 'to proclaim the gospel to their neighbors and family. (p. 62)

The church as Body of Christ is also important. This means that there is a direct relation between the living Christ and the people living as community and congregation. The living Christ brings about new life and new relations in His Body. Participation, community and identity are all extremely important regarding the church as body of Christ (Migliore 2004:254). Christ is the head of the church; there is no church where Christ is not present. It is extremely important that this Christ is God from God, verily God from verily God, light from light. He is the Son of God in glorious relation with the Father. He is One with God, and He lives in this relation with the living God. The church is the body of Christ, the body of the crucified Christ and the resurrected Christ. The Body of Christ is, therefore, a body of people closely linked to the crucifixion and resurrection. The crucifixion is essential to understand the church as the body of Christ because the church was bought at the highest price. Christ brings about redemption and glory for the church. Van Aarde (2015:54) explains this effectively: 'God's plan is to gather everything into a living unity with him. He takes the initiative to reveal his purpose and plan for the church (Eph. 1:23)'.

The church is called to be the body of Christ, as exemplified below:

Romans 12:5: 'so in Christ we, although many, form one body and each member belongs to all the others'.

1 Corinthians 12:12: 'Just as a body, although one, has many parts, but all its many parts form one body, so it is with Christ'.

The church of Christ is a complete whole as the organs in the body are part of the one body. As body of Christ, the church is the community that lives in unity with one another and Christ (Conzelmann 1975:s.p.).

Mare (1976:s.p.) also emphasises the unity in the body of Christ. The missional church should then also be an example in unity to the larger community. It is also important to realise that Paul's view on the church as body of Christ is countercultural. New relations are presented and the body of Christ is a new family different from the environment in which they find themselves (DeSilva 2004:570). The image of the body also presents the very important aspect of unity and diversity. The body of Christ is one in Christ. However, one must also accept diversity. The diversity must not avoid the unity and the unity must not reject the unity (Fee 1993:583). As a new community, the church lives in unity and diversity. It can become an example for the whole world.

\section{Ephesians 3:6:}

This mystery is that, through the gospel, the Gentiles are heirs together with Israel, members together of one body, and sharers together in the promise in Christ Jesus.

\section{Colossians 1:18:}

And he is the head of the body, the church; he is the beginning and the firstborn from among the dead, so that in everything he might have the supremacy.

Moses (2018:474) refers to the importance of the body of Christ: 'In this vision the body of Christ (crucified and gathered) becomes the space where the powers are unmasked and defeated'. He also stated that: 'Paul knows that poor believers are part of the body of Christ and the body of Christ is a place where believers practice the self-sacrificing love of Christ' (Moses 2018:489).

What does this mean for mission? Mission means that the body of Christ must always glorify Christ, and the body of Christ must always proclaim the Living Christ. It must be the proclamation of the glory of the Living Christ in the world. Groppe (2019) links this to the eucharist:

The place where the wounds of the Body of Christ are most starkly visible, and the place where our restored communion will be most fully celebrated, is the eucharistic liturgy. (p. 25)

The church as the temple of God means that the church should be a community that is not of this world. It should be a community that lives according to the Word of God. It should be an ethical community of new life. The church must be the community proclaiming Christ as the glorious Son of God to whom all should belong. This can only be done if the church understands its task in the world as a task of holiness. The church should be a Holy church living from the Holiness of God. Van Engen (1991) also explains this in his book. The church should be One Holy apostolic church. The holiness of the church as temple of God is essential. van Niekerk and Niemandt (2019:8), however, gave much attention to the concept of deep incarnation. This means that one should acknowledge the incarnation of Christ in this world. It has implications for the coming of the kingdom of God already in this world. It implies that all aspects of creation are renewed in Christ. It is important for the understanding of the church as temple of God and the way in which the incarnation should be regarded. One must, however, point out that the new world in Christ always has to do with his regeneration of it in the parousia. 
The church should live as God's temple. This is clear in 1 Corinthians 3:16: 'Don't you know that you yourselves are God's temple and that God's Spirit dwells in your midst?'

2 Corinthians 6:16 also emphasises this:

What agreement is there between the temple of God and idols? For we are the temple of the living God. As God has said: 'I will live with them and walk among them, and I will be their God, and they will be my people'.

Martin (1998) explains this succinctly:

The tie with the world had to be broken so that the temple of God would be pure. An important result of this failure to cleanse themselves was that the true ambassador for God was likewise shut out of the Corinthians' lives, and they had ranged themselves on the side of the unbelieving world which needs to be 'reconciled' - as they did insofar that they were opposing Paul's Gospel. (s.p.)

This means that the church as temple of God should be a community of holiness. The church's thinking should be different from the world and should be on Christ and his revelation (DeSilva 2004:586).

Page (2020) explains the implications of this truth as:

Believers are said to be the Temple of God (1 Corinthians 3:6-17), so much of what was said of the Temple is likely now to be able to be said of believers. (p. 9)

The church as the Bride of Christ is the glorious Son of God, and the church is the Bride of Christ in the sense that the church is Living with Christ in this world. The glorious second coming of Christ, the parousia, will be the glorious exclamation of the Living Christ. The bride lives in the expectation of the Bridegroom's coming. The bride is, therefore, in this world, yearning for the coming of Christ and for the Word of God, longing for Him to be with her and, in that sense, also proclaiming the parousia of the living Christ. He will come again, and He will be the glorious Son of God who fulfils His promises to regenerate the church. This is evident in Ephesians 5:25. Van Zyl and Nortjé-Meyer (2018:6) explained: 'The love that Christ exhibits is self-giving (Eph 5:25.), and the corporate life of the Christian community is to be the social embodiment of the self-giving and loving Christ'.

Ademiluka (2020) also refers to this important aspect:

But the concept is fully developed in Ephesians 5:25-27 where he describes the husband's duty towards his wife: Husbands, love your wives, as Christ loved the church and gave himself up for her, that he might sanctify her, having cleansed her by the washing of water with the word, that he might present the church to himself in splendor, without spot or wrinkle or any such thing, that she might be holy and without blemish (RSV). (p. 5)

Other texts in Revelation also emphasise this:

Revelation 21:9:

One of the seven angels who had the seven bowls full of the seven last plagues came and said to me, 'Come, I will show you the bride, the wife of the Lamb'.

\section{Revelation 19:7:}

'Let us rejoice and be glad and give him glory! For the wedding of the Lamb has come and his bride has made herself ready'.

Aune (1998:s.p) explains that it is important to note the relation of the church as bride and Christ as bridegroom. Evidently the metaphor that was known in early Christian times emphasises the task of the missional church to be pure before God (see also 2 Cor 11:2).

The image is in relation to biblical marriage customs with the marriage feast following the betrothal. The church awaits the wedding feast of the parousia as the bride awaits the coming of the bridegroom (Mounce 1990:340).

Those who are invited to God's feasts are the bride and they are opposed to those who reject Him. They are worshipping God and not the idols and they fear only God (DeSilva 2004:910).

\section{Revelation 22:17:}

The Spirit and the bride say, 'Come!' And let the one who hears say, 'Come!' Let the one who is thirsty come; and let the one who wishes, take the free gift of the water of life.

DeSilva (2004:910) emphasises that the bride of Christ stands diametrically opposed to those who worship idols and not Christ. An element of discernment is thus necessary to know who belongs as the bride of Christ to Him.

\section{Shealy (2012) opines:}

Church does not progress from bride to mother as one would expect given the pattern for women of marriage then motherhood; rather, she advances from earthly mother to heavenly bride Eph. 5:26. (p. 4)

The church is really called to be witnesses in the world. Therefore, a church is also the witness of God and is a special relation of the mission of the church. The church is a servant church and should always humbly witness to God. Living with the expectation of the new life in Christ, the church witnesses to the world that God is the living God and that new life is possible in Him (Migliore 2004:254).

Guder (2005) explains this clearly:

When one examines the imperatives in the New Testament epistles, it becomes very clear that the 'work' of early Christians was their 'witness'. Every dimension and aspect of their life before a watching world, to borrow John Howard Yoder's oft cited phrase, was crucial to their witness. Witness was, as we said above, not one of several activities, but the description of who they were and what they were for. (p. 430)

Niemandt (2015a) also refers to the World Council of Churches' report 'Together Towards Life', explaining that the witness of the church is all-encompassing. He summarised it as follows:

The significance of 'mission with creation at its heart' is that mission in God's way extends to God's creation, and that participating in life-giving mission is a crucial part of the church's 
mission. This entails, at the very least, missiological reflection on appropriate lifestyles and practices as part of Christian mission, and means that eco-justice becomes fundamental to mission. The economic solution has moved to the centre of the stage. One of the significant effects is that poverty and affluence have diametrically grown beyond all expectations. The problem is a destructive consumerism, driving people apart. This calls for a serious reflection from the ecumenical community and creative ideas on appropriate lifestyles and practice. (p. 95)

Acts 5:32 refer to the aspect of proclamation: 'We are witnesses of these things, and so is the Holy Spirit, whom God has given to those who obey him'.

\section{Acts 1:8:}

But you will receive power when the Holy Spirit comes on you; and you will be my witnesses in Jerusalem, and in all Judea and Samaria, and to the ends of the earth.

Robinson (2019:141) opines: 'Any congregation which seeks to be faithful to the gospel must consider what it means to be Jesus' witness in the world'.

\section{Garstecki (2019) explains:}

The authors of the guidelines do not speak in their text of 'Christians' service for peace', but deliberately argue from the standpoint of the church's witness to and service for peace. (p. 376)

The church as the witness of the glory of God in the world must go out into the world to witness to the world of the glory of Christ. In that sense, mission has everything to do with witness, the church cannot be silent. Not living for herself, the church is a servant to God and the world (Migliore 2004:253). The church as witness is not only proclamation but also koinonia, diakonia and marturia even in the sense that the church often offers itself as the church that yields itself for building up the people around her. Therefore, the church should always be the church of mission. The church can never turn its back on mission; it should always be a church of mission; going into the world, proclaiming God, proclaiming the glory of God, so that the church can be the glorious church of mission, telling people about the glorious love of God in Jesus Christ.

Manyaka-Boshielo (2018) lists a few radically important aspects to be considered, namely participation, capacitybuilding, access to information, accountability and local organisations.

As witness, the church has to proclaim that conversion is necessary. This means, like the prophets of old, calling the world to repentance. The church also has to call the world to repentance to a change in view, to radical coming back to God and explaining that it has to be servants to God, who has to be proclaimed. In this sense, the church sometimes finds itself as a church that is being rejected. The church often suffers persecution. The glory of God and all the wonders of God must be proclaimed, even under persecution. The church of persecution is also the church of God, and when it is persecuted, the church must also remain true to its calling, namely to proclaim that Jesus is Lord even under persecution. The church must do this under all circumstances, even when it is very difficult to do that, because the church is called to proclaim the Word of God. The church can only be the prophet in the name of Jesus Christ, who calls the world to repentance, back to Jesus Christ, so that the wonders of Christ can be understood and the glory of Christ can be proclaimed throughout the world by remaining true to Christ. Armstrong (2015:241) writes '...to pursue unity in mission by becoming Spirit-filled, joyful communicators of the good news, in both word and deeds'. Pillay (2015) explains: 'The church does not exist just for believers, it actually exists for the world: To lead others to Jesus'.

One must, however, see this aspect, namely that the church is a witness always in relation to the calling of the church to be rather than to speak. In this regard, the missional church as witness has to live a new life in the society and in the community. One should not separate the new life in Christ as witness from being a witness in the life of the church. As important as the proclamation of Jesus as Lord, is the Spiritfilled life with Him. In this regard Guder (2015) writes:

We could examine the community's acts of prophetic challenge in interaction with the world into which it is sent, its conscious alternativeness in its larger context, as worthy parables of Christ's kingdom breaking in. (p. 143)

The church in prophetic witness points to a new world in Christ. It has implications not only for the present but also for the future.

\section{Conclusion}

Jørgensen (2004) shows the way forward for the church:

There is no room for the triumphalism and ecclesial joy of power of the past. Instead, there is a need for a servant church inspired by the new churches - also because the greatest integrity and vitality today are found among the churches that have experienced martyrdom. (p. 560)

One of the most important issues is how one should view the relation between the church and the community. The missional church emphasises the fact that the church is God's new community living in the secular world. The missional church regards the task to get involved from the perspective of the missio Dei.

The relation of the living church is the relation with the living Christ. Some important guidelines should be maintained:

- As people of God, the church is the new Israel, acknowledging the glory of the Saviour Christ and living holy lives among the people. The church is the true assembly of love.

- As body of Christ, the church belongs to Christ. A radical Christological approach is always necessary. In Christ the church is the new community of God.

- As temple of God, the church is holy and should live accordingly in the world. The church is not rejecting the world but is in the world to bring about change in Christ's name. 
- As bride of Christ, the church is the special community belonging to Christ and receives her glory from God.

- As witness, the church proclaims the wonders of the living God prophetically. This is not only proclamation in word but also in deed.

- Looking to the future, the church is a group of pilgrims on their way to glory, but already glorifying God here and now.

It is necessary to acknowledge that the church is Christ's. In the challenging world there is a community belonging to God serving Him and the world by confessing Christ. Therein lies the hope of the world.

\section{Acknowledgements Competing interests}

The author declares that he has no financial or personal relationships that may have inappropriately influenced him in writing this article.

\section{Author's contributions}

P.V. is the sole author of this article.

\section{Ethical considerations}

This article followed all ethical standards for research without direct contact with human or animal subjects.

\section{Funding information}

This research received no specific grant from any funding agency in the public, commercial or not-for-profit sectors.

\section{Data availability}

Data sharing is not applicable to this article as no new data were created or analysed in this study.

\section{Disclaimer}

The views and opinions expressed in this article are those of the author and do not necessarily reflect the official policy or position of any affiliated agency of the author.

\section{References}

Ademiluka, S., 2020, "For the husband is the head of the wife": A contextual rereading of Ephesians 5:22-33 among Nigerian Yoruba Christians', In Die Skriflig 55(1), 1-10. https://doi.org/10.4102/ids.v54i1.2613

Armstrong, J.H., 2015, 'The church in the contemporary ecumenical-missional moment: Together towards life in dialogue with the Cape Town Commitment and Evangelii Gaudium', International Review of Mission 104(2), 232-241. https://doi. org/10.1111/irom.12098

Aune, D.E., 1998, Revelation 17-22 (Word Biblical Commentary Volume 52c.), Word, Dallas, TX.

Baron, E., 2019, 'The 1619 Dordrecht Synod's decision on corruptio totalis: A missional challenge for the church in terms of media reporting on corruption in South Africa', In Die Skriflig 53(3), 1-9. https://doi.org/10.4102/ids.v53i3.2407

Baron, E. \& Maponya, M.S., 2020, 'The recovery of the prophetic voice of the church: The adoption of a "missional church" imagination', Verbum et Ecclesia 41(1), 1-9. https://doi.org/10.4102/ve.v41i1.2077

Bell, R., 2011, Love wins: At the heart of life's big questions, Collins, London.
Billings, J.T., 2008, 'What makes a church missional? Freedom from cultural captivity does not mean freedom from tradition', Christianity Today 52(3), 56-59.

Bosch, D.J., 1991, Transforming mission: Paradigm shifts in theology of mission, Orbis, New York, NY.

Carpenter, E., 1997, 'קהל', in W.A. Van Gemeren (ed.), New International dictionary of Old Testament theology and exegesis, pp. 888-892, Zondervan, Grand Rapids, MI.

Conzelmann, H., 1975, 1 Corinthians: A commentary on the first epistle to the Corinthians, transl. James W. Leitch, Fortress, Philadelphia, PA.

DeSilva, D.A., 2004, An introduction to the New Testament contexts, methods, and ministry formation, IVP Academic, Downers Grove, IL.

Eichrodt, W., 1967, Theology of the Old Testament, vol. 2, transl. J.A. Baker, Westminster, Philadelphia, PA.

Fee, G.D., 1993, The first epistle to the Corinthians, The New International Commentary on the New Testament, Eerdmans, Grand Rapids, MI.

Flemming, D., 2014, “'Won over without a word": Holiness and the church's missional identity in 1 Peter', Wesleyan Theological Journal 49(1), 50-66.

Garstecki, J., 2019, 'The peace work and witness of the churches in the German Democratic Republic and the world disorder of the 21st century', The Ecumenical Review 71(3), 371-388. https://doi.org/10.1111/erev.12430

Goheen, M.W., 2014, Introducing Christian mission today: Scripture, history and issues, IVP Academic, Downers Grove, IL.

Groppe, E., 2019, 'Longing for communion fifty years after Unitatis Redintegratio: Envisioning a ministry of hospitality and healing in a wounded body of Christ', Worship 3, 12-31.

Guder, D.L., 1998, Missional church: A vision for the sending of the church in North America, Eerdmans, Grand Rapids, MI.

Guder, D.L., 2005, 'Worthy living: Work and witness from the perspective of missional church theology', Word \& World 25(4), 424-432.

Guder, D.L., 2015, Called to witness: Doing missional theology, The gospel and our culture series (GOCS), Eerdmans, Grand Rapids, MI.

Hughson, D.T., 2011, 'Missional churches in secular societies: Theology consults sociology', Ecclesiology 7(2), 173-194. https://doi.org/10.1163/174553111X559445

Jørgensen, K., 2004, 'The emergence and challenge of the missional church concept in the West', Svensk Missionstidskrift 92(4), 551-571.

Macllvaine, W.R. III., 2010, 'What is the missional church movement?', Bibliotheca Sacra 167(665), 89-106.

Manyaka-Boshielo, S.J., 2018, 'The role of a missional social entrepreneurial church in a township community', HTS Teologiese Studies / Theological Studies 74(1), 1-8. https://doi.org/10.4102/hts.v74i1.4932

Mare, W.H., 1976, 1 Corinthians (The Expositor's Bible Commentary, volume 10), ed. Frank E. Gæbelein, Zondervan, Grand Rapids, MI.

Martin, R.P., 1998, 2 Corinthians (Word Biblical Commentary, vol. 40), Word, Dallas, TX.

Migliore, D.L., 2004, Faith seeking understanding: An introduction to Christian theology, 2nd edn., Eerdmans, Grand Rapids, MI.

Moses, R., 2018, 'Discerning the body of Christ: Paul, poverty and the powers', Journal for the Study of the New Testament 40(4), 473-493. https://doi. org/10.1177/0142064X18770072

Mounce, R.H., 1990, The Book of Revelation (The New International Commentary on the New Testament), Eerdmans, Grand Rapids, MI.

Newbigin, L., 1989, The gospel in a pluralist society, Eerdmans, Grand Rapids, MI.

Niemandt, C.J.P., 2012, 'Trends in missional ecclesiology', HTS Teologiese Studies/ Theological Studies 68(1), a1198. https://doi.org/10.4102/hts.v68i1.1913

Niemandt, C.J.P., 2014, 'Artisanal cheeses or artisanal Jesus - Loving your postal code enough to reflect it in the life and theology of the church', Missionalia 42(1-2) 38-54. https://doi.org/10.7832/42-1-2-45

Niemandt, N., 2015a, 'Together towards new life for missiology?: Mission and missiology in the light of the World Council of churches 2013 policy statement', Acta Theologica 35(2), 82-103. https://doi.org/10.4314/actat.v35i2.6

Niemandt, C.J.P., 2015b, 'Together towards life: Sailing with pirates', Missionalia 43(3), 336-348. https://doi.org/10.7832/43-3-88

Nikolajsen, J.B., 2013a, 'Missional church: A historical and theological analysis of an ecclesiological tradition', International Review of Mission 102(2), 249-261. https://doi.org/10.1111/irom.12028

Page, B., 2020, 'Inaugurated hyperspace', An International Journal for Philosophy of Religion and Philosophical Theology 4(3), 1-21. https://doi.org/10.14428/thl. v4i3.54843

Peterson, C.M., 2015, 'An ecclesia and missio crucis: Douglas John Hall's contribution to the missional church conversation', Dialog 54(2), 162-170. https://doi. org/10.1111/dial.12171

Pillay, G.J., 2015, 'The missional renaissance: Its impact on churches in South Africa, ecumenical organisations, and the development of local congregations', HTS Teologiese Studies / Theological Studies 71(3), 1-6. https://doi.org/10.4102/hts. v71i3.3065

Prebble, E., 2014, 'Missional church: More a theological (re)discovery, less a strategy for parish development', Colloquium 46(2), 224-241.

Preuss, H.D., 1996, Old Testament theology part 2, transl. Leo G. Perdue, John Knox Press, Westminster.

Pryfogle, D., 2018, 'Ekklesia as enterprise: Discovering the church at work', Review and Expositor 115(3), 372-377. https://doi.org/10.1177/0034637318786673 
Robinson, E., 2019, 'Witness, the church, and faithful cultural engagement' Missiology: An International Review 47(2), 140-152. https://doi.org/10.1177/ Mo91829619828129

Shealy, W., 2012, 'The church as bride and mother: Two neglected theological metaphors', JFDM 2(2), 4-32.

Van Aarde, T., 2015, 'The use of oikovouia for the missional plan and purpose of God in Ephesians 1:3-14', Missionalia 43(1), 45-62. https://doi.org/10.7832/43-1-43

Van Engen, C., 1991, God's missionary people: Rethinking the purpose of the local church, Baker, Grand Rapids, MI.

Van Engen, C., 1996, Mission on the way: Issues in mission theology, Baker, Grand Rapids, MI.
Van Gelder, C., 2004, 'From corporate church to missional church: The challenge facing congregations today', Review \& Expositor 101(3), 425-450. https://doi. org/10.1177/003463730410100306

Van Niekerk, P. \& Niemandt, N., 2019, 'The radical embodiment of God for a Christology of a new era', HTS Teologiese Studies/Theological Studies 75(1) a5633. https://doi.org/10.4102/hts.v75i1.5633

Van Rheenen, G., 2006, 'Contrasting missional and church growth perspectives', Restoration Quarterly 48(1), 25-32. https://doi.org/10.1177/875687050602500106

Van Zyl, C. \& Nortjé-Meyer, L., 2018, 'The metaphor of "walking in love" as matrix for the relationships in Ephesians 5:22-6:9', Pharos Journal of Theology 99, 1-12.

Wright, C.J.H., 2006, The mission of God: Unlocking the Bible's grand narrative, InterVarsity, Nottingham. 